\title{
Enhancing access to post-rape care for child survivors in the context of police and health services in Zambia: A feasibility assessment of a police response model
}

\author{
Nachela Chelwa \\ Population Council \\ Kshipra Hemal \\ Population Council \\ George Msipu Phiri \\ Michael Mbizvo \\ Population Council \\ Chi-Chi Undie \\ Population Council
}

Follow this and additional works at: https://knowledgecommons.popcouncil.org/departments_sbsr-rh

Part of the Demography, Population, and Ecology Commons, Domestic and Intimate Partner Violence Commons, Family, Life Course, and Society Commons, International Public Health Commons, and the Maternal and Child Health Commons

How does access to this work benefit you? Let us know!

\section{Recommended Citation}

Chelwa, Nachela, Kshipra Hemal, George Msipu Phiri, Michael Mbizvo, and Chi-Chi Undie. 2017.

"Enhancing access to post-rape care for child survivors in the context of police and health services in Zambia: A feasibility assessment of a police response model." Lusaka: Population Council. 
Enhancing Access to Post-Rape Care for Child Survivors in the Context of Police and Health Services in Zambia:
A Feasibility Assessment of a Police Response Model

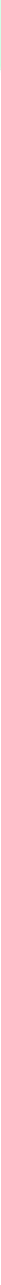

POPULATION
COUNCIL
Ideas. Evidence. Impact.
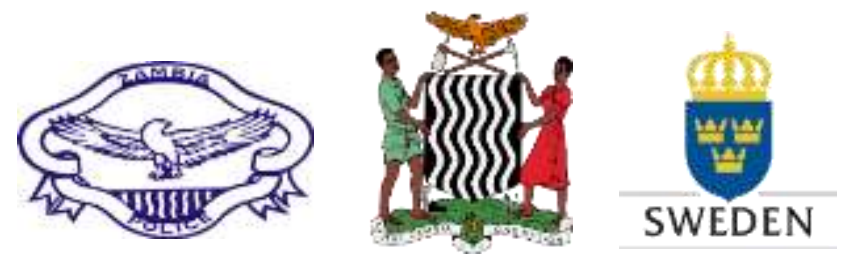

Norad 
Enhancing Access to Post-Rape Care for Child Survivors in the Context of Police and Health Services in Zambia

A Feasibility Assessment of a Police Response Model

November 2017

Nachela Chelwa', Kshipra Hemal', George Msipu Phiri', Michael T. Mbizvo' and Chi-Chi Undie $^{3}$

'Population Council, Zambia

${ }^{2}$ Zambia Police Service

${ }^{3}$ Population Council, Kenya

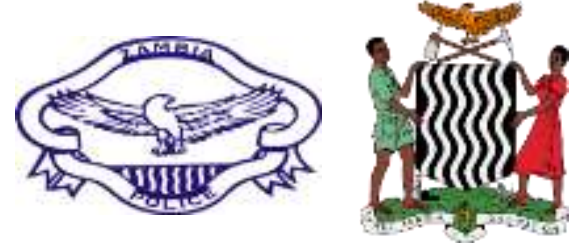


The Population Council confronts critical health and development issues-from curbing the spread of HIV to improving reproductive health and ensuring that young people lead full and productive lives. Through biomedical, social science, and public health research in 50 countries, we work with our partners to generate and synthesize research evidence towards solutions that lead to more effective policies, programs, and technologies to improve health and save lives around the world. Established in 1952 and headquartered in New York, the Council is a nongovernmental, nonprofit organization governed by an international board of trustees.

Population Council Plot No. 3670 4, Mwaleshi Road,

Olympia Park.

P/Bag Rw319x,

Lusaka, Zambia

Tel: +260 21 I 295925 email: info.zambia@popcouncil.org popcouncil.org

Suggested citation: Nachela Chelwa, Kshipra Hemal, George Msipu Phiri, Michael T. Mbizvo and ChiChi Undie. 2017. Enhancing Access to Post-Rape Care for Child Survivors in the Context of Police and Health Services in Zambia: Report on a Police response model tested in Zambia. Lusaka: Population Council. 


\section{Acknowledgements}

The study would have not been possible without the commitment and support of the Government of the Republic of Zambia. The Zambia Police Service (ZPS) supported the study at all levels, from the Office of the Inspector General, to the dedicated Victim Support Unit (VSU) Officers in the field. Mr. Tresphord Kasale, Director of Community Services Department; Mr. Collins Hikalinda, National VSU Coordinator; Insp. Archaje Magai, VSU HQ; Ms. Susan Liteta, National Child Protection Officer, ZPS; Mrs Namatama S. Chinyama, Assistant Director, Ministry of Gender; Mr. Nsofwa, Criminal Investigation Unit; and Dr. Eugene Kaunda, Obstetrician/Gynaecologist, Ministry of Health, were cardinal in designing and rolling out Health worker and Police trainings in Lusaka.

Dr. George Msipu Phiri, Director of Medical Services, ZPS, and the Sikanze Police Hospital team, helped to ensure that access to emergency contraceptives via the Police Hospital pharmacy was guaranteed and supported the refresher training for VSU officers from Chawama and Kanyama.

Data collection would not have been undertaken without the dedication of the data collection team comprising Mr. Davies Mpala, VSU Co-ordinator, Chawama; Mr. George Makovwa, VSU Co-ordinator, Kanyama; Mrs. Lisa Wamulume, VSU Officer Chawama; Mr. Harry Mbulo, VSU Officer, Kanyama; and two Council researchers: Ms. Gladys Kamanga and Mr. Lawrence Muleba.

This study received financial support from the Regional Team for Sexual and Reproductive Health and Rights, Embassy of Sweden, Lusaka, Zambia. 


\section{Table of Contents}

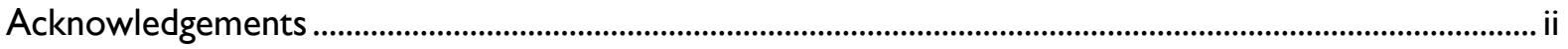

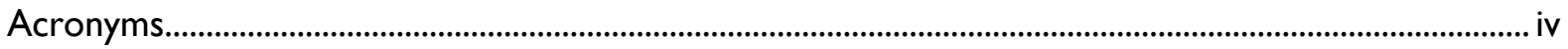

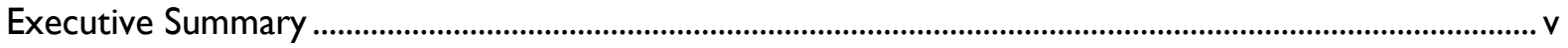

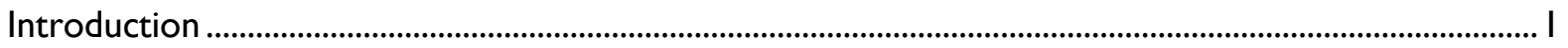

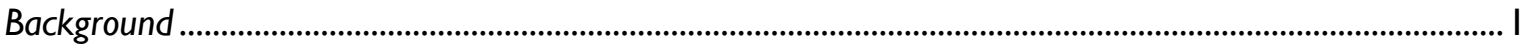

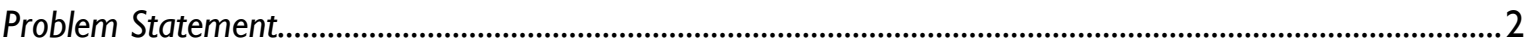

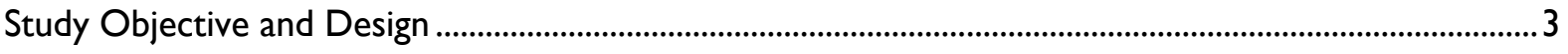

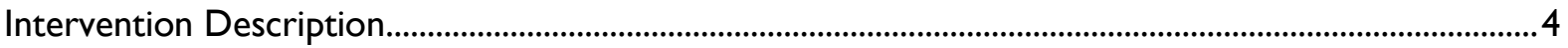

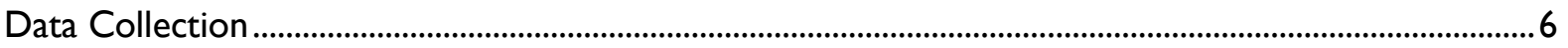

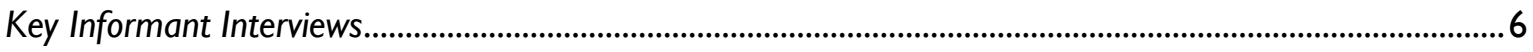

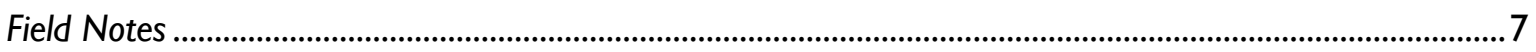

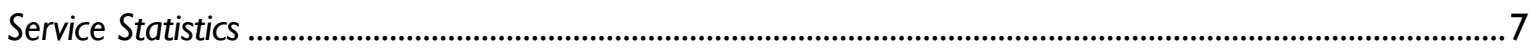

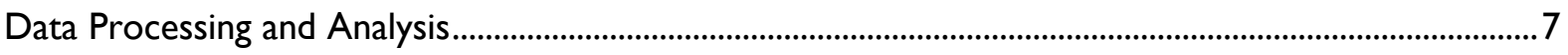

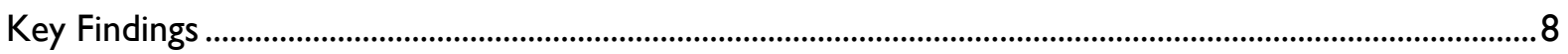

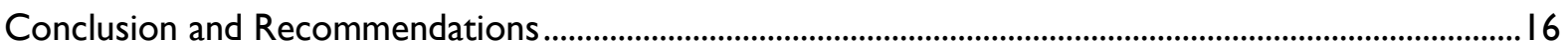

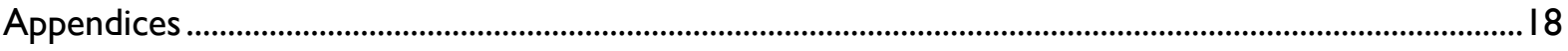

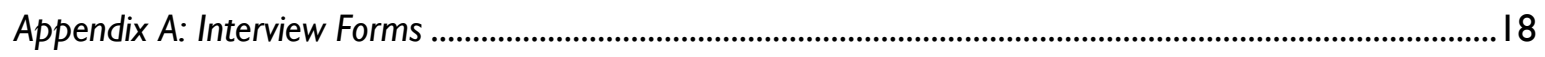

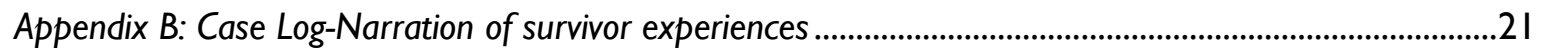




\section{Acronyms}

ART Anti-Retroviral Therapy

ECP Emergency Contraceptive Pill

$\mathrm{MOH}$ Ministry of Health

PEP Post-Exposure Prophylaxis

UTH University Teaching Hospital

VAC Violence Against Children

VSU Victim Support Unit

ZPS Zambia Police Service 


\section{Executive Summary}

This study builds on previous interventions by the Population Council and the Zambia Police Service to mitigate unintended pregnancy and HIV among survivors of sexual violence by involving trained police in task-sharing interventions. These previous efforts have involved police providing emergency contraceptive pills and HIV post-exposure prophylaxis to survivors reporting to police stations, in addition to referrals to health facilities. Transportation barriers limited the feasibility of these interventions. The objective of the current study was therefore to assess the feasibility of implementing a transportation intervention within police stations, coupled with training and sensitization for police officers to perform their government-mandated roles in post-rape care. This intervention was developed as a means of enhancing children's access to comprehensive post-rape care in Zambia, and was implemented over a three-month period, from February to April 2017.

Two police stations (Chawama and Kanyama police stations) and one hospital (University Teaching Hospital) in Lusaka Province, served as the study sites. An explanatory case study design was employed for the assessment, drawing on qualitative and quantitative data. The following data were collected: semi-structured, key informant interviews with a total of 22 police, health providers, and caregivers of child survivors presenting at police stations; fieldnotes of $2 \mathrm{l}$ observations as police accompanied child survivors and caregivers to UTH; and service statistics of the police-accompanied hospital visits.

The study confirmed the feasibility of implementing a package of interventions involving I) police and health provider training/sensitization, and 2) the introduction of supportive transportation services for child survivors within police stations. The study findings with regard to each intervention component are summarized below:

- Police and health provider training and sensitization on the National Guidelines for the Multidisciplinary Management of Survivors of Gender-Based Violence in Zambia helped strengthen the multi-sectoral response to the needs of child survivors of rape;

- Transportation within police stations proved critical for improving child survivors' access to comprehensive care; and

- Police accompaniment of child survivors from police stations to the health facility site eased the health facility encounter for child survivors and caregivers.

The study concluded that while this package of interventions enhances child survivors' access to comprehensive services, post-rape care service delivery in health facilities must be strengthened for greater efficiency.

A series of recommendations, described below, were generated to help support the operationalization and sustainability of the package of interventions to strengthen the capacity of police officers to provide post-rape care

I. Sensitize providers to their roles in the National Guidelines: Incorporate National Guidelines sensitization into police, health, and legal pre-service and in-service training at all levels.

2. Build the capacity of providers: Develop and implement training curricula for police, health, and legal providers, drawing specifically on the National Guidelines to ensure that providers are equipped to play their mandated roles. This training should also be integrated into pre-service and in-service training for the various sectors. 
3. Experiment with transport facilitation models for Victim Support Units: Given the importance of transportation for the success of this intervention, innovating with affordable transportation models would be important to identify cost-effective options. Possible models could include the development and use of public transportation stipends, and the provision of motorized rickshaws.

4. Update National Guidelines: Review the National Guidelines to update guidance on provider roles (police, health, legal) to facilitate a multi-sectoral response in both One-Stop Centers (OSCs) and non-OSCs.

5. Strengthen health facilities: Prepare health facilities (OSCs and non-OSCs) to promote an effective multi-sectoral response by addressing understaffing and ensuring that administrative costs (e.g., costs of photocopying) are not borne by survivors. 


\section{Introduction}

\section{Background}

Sexual violence, as defined by the World Health Organization, includes "any sexual act, attempt to obtain a sexual act, unwanted sexual comments or advances, or acts to traffic, or otherwise directed, against a person's sexuality using coercion, by any person regardless of their relationship to the victim, in any setting, including but not limited to home and work." Victims of sexual violence, in particular children, suffer long-term psychological trauma and experience adverse health consequences, including transmitted infections such as HIV and early unwanted pregnancies. This study focuses specifically on one coerced sexual act against minors: rape (or completed, forced penetration of a survivor).

Under the Zambian Penal Code, completed, forced penetration is referred to as 'defilement' in the case of child survivors, and as 'rape' where adult women survivors are concerned. The Zambian constitution, amended in January 2016, defines a child as ".... person who has attained, or is below, the age of eighteen years old" (Article 266). ${ }^{2}$ For the purposes of this study, we focus on child survivors of defilement $-\mathrm{a}$ term that we use interchangeably with 'rape' in this report.

The regional prevalence of child rape is high: Violence Against Children (VAC) surveys in East and Southern African countries indicate that about I in 3 girls and I in 5 boys experience sexual violence (of which rape is a part) before they turn $18 .{ }^{3}$ In the 2014 Zambia VAC survey ${ }^{4}$ - the first national survey of violence against children in the country - $20 \%$ of females and $10 \%$ of males aged $18-24$ reported experiencing some form of sexual violence (including, but not limited to, forced sex) prior to their $18^{\text {th }}$ birthday. ${ }^{5}$ Of these, no girls reported receiving services for the sexual violence incident, compared to $7 \%$ of boys.

A Zambia-based qualitative study indicated that defilement was the most commonly cited problem among child respondents, ${ }^{6}$ and, despite acknowledged high levels of underreporting by survivors, National Gender Crime Statistics indicate that 2,759 cases of defilement were reported to the Zambian police in 2015 alone.,7 Moreover, findings from two Population Council studies consistently highlight the prominence of adolescents as service seekers within police stations in Zambia: A 2005 study found that $85 \%$ of survivors who reported to police stations were under the age of 19,8 and a

\footnotetext{
I Krug, E.G., et al., World Report on Violence and Health, World Health Organization, Geneva, 2002.

2 Constitution of Zambia (Amendment) Act No.2 of 2016.

3 Reza A, Breiding MJ, Gulaid J, Mercy JA, Blanton C, Mthethwa Z, Bamrah S, Dahlberg LL, Anderson M. (2009). -Sexual violence and its health consequences for female children in Swaziland: A cluster survey study.ll The Lancet. 373 (9679): 1966-1972; UNICEF, CDC, MUHAS, 20II. Violence against Children in Tanzania: Findings from a National Survey, 2009. Summary Report on the Prevalence of Sexual, Physical and Emotional Violence, Context of Sexual Violence, and Health and Behavioural Consequences of Violence Experienced in Childhood. Dar es Salaam, Tanzania: UNICEF Tanzania, Division of Violence Prevention, National Center for Injury Prevention and Control, Centers for Disease Control and Prevention, and Muhimbili University of Health and Allied Sciences, 20I I; Zimbabwe National Statistics Agency, 2012. National Baseline Survey on Life Experiences of Adolescents (Preliminary Report) 2012.

${ }^{4}$ Also referred to as the 'Zambia Health and Wellbeing Survey [H-WELL].'

5 Zambia Health and Wellbeing Survey Policy Brief [H-WELL]. http://www.togetherforgirls.org/wpcontent/uploads/2017//0/PS.HWELL-Zambia-Data-Brief.pdf.

6 Murray, Laura K. et al. "Violence and Abuse Among HIV-Infected Women and Their Children in Zambia: A Qualitative Study." Journal of Nervous and Mental Disease 194.8 (2006): 610-6I5.

72015 National Gender Based Violence Crime Statistics by Province (Zambia Police Service - Victim Support Unit)

8 Keesbury, Jill, Mary Zama, and Sudha Shreeniwas. 2009. "The Copperbelt Model of Integrated Care for Survivors of Rape and Defilement: Testing the feasibility of police provision of emergency contraceptive pills." Lusaka: Population Council.
} 
2013 study found that about $85 \%$ of survivors reporting to police stations were aged 10 to 16 years, with the mean age of these presenting being 13 years. ${ }^{9}$ Girls below the age of 10 represented nearly a quarter $(23 \%)$ of sexual violence reports to police stations under this study.

The risks associated with defilement are numerous. Immediate health consequences include unwanted pregnancy, physical trauma, emotional distress and the acquisition of HIV and other sexuallytransmitted infections. ${ }^{10}$ Long-term consequences include a range of risk behaviors and disorders such as smoking, obesity, high-risk sexual behaviors, and depression. These, in turn, can be linked to cancer, heart disease, and suicide."

Some of the immediate risks can be mitigated if the survivor receives psychosocial and medical support soon after sexual violence occurs. If delivered within 120 hours of unprotected sex, the emergency contraceptive pill (ECP) is effective in preventing unwanted pregnancy. ${ }^{12}$ To prevent HIV infection, HIV post-exposure prophylaxis (PEP) - an initial dose of anti-retroviral therapy (ART) - can be given within 72 hours of exposure. ${ }^{13}$ Similarly, forensic evidence collection is time-sensitive and is also recommended within 72 hours of the assault. ${ }^{14}$ Thus, responding within 72 hours is critical to ensuring the survivor's health and the ability to prosecute the case. This means that timely coordination between the medical and legal sectors is a basic prerequisite for effective post-rape care for child survivors, and solutions are needed for ensuring that such coordination occurs.

\section{Problem Statement}

In $201 \mathrm{I}$, Zambia made considerable progress by adopting a comprehensive response protocol via the first-ever National Guidelines for the Multidisciplinary Management of Survivors of Gender Based Violence. This document outlines the coordinated actions to be taken by the health, police and social services sectors in response to sexual violence and includes special considerations for child survivors. Notably, the National Guidelines allow the police to provide ECPs to survivors presenting at police stations. Additionally, the guidelines require police officers to escort survivors to the nearest health facility to ensure that comprehensive medical treatment is provided to survivors.

\footnotetext{
9 Mary Zama, Mardieh Dennis, Jessica Price, Stephanie Topp, Jonathan Kaunda Mwansa and Jill Keesbury. 20I3. Mitigating the Consequences of Sexual Violence in Zambia by Decentralizing Emergency Medical Responses to Police Victim Support Units: Report on the Feasibility of Police Provision of Post-Exposure Prophylaxis for HIV (PEP) in Zambia. Lusaka: Population Council.

10 Lindegren, Mary Lou, et al. "Sexual abuse of children: intersection with the HIV epidemic." Pediatrics I02.4 (I998): e46e46; Speight $C$ et al. 2006. Piloting post-exposure prophylaxis in Kenya raises specific concerns for the management of childhood rape. Transactions of the Royal Society of Tropical Medicine and Hygiene 100: 14- 18; Drocton P, et al. 2008. Validation set correlates of anogenital injury after sexual assault. Academy of Emergency Medicine 15: 23I-38; Girardet Ret al. 2009. HIV post-exposure prophylaxis in children and adolescents presenting for reported sexual assault. Child Abuse and Neglect 33: 173-78; Hilden M, et al. 2005. Genitoanal injury in adult female victims of sexual assault. Forensic Science International I54: 200-205.

"I Jewkes R, et al., Sexual violence [Chapter 6]. In: Krug, E.G., et al., World report on violence and health. Geneva, Switzerland: World Health Organization; 2002:147-82.

12 Trussell J, et al. 2004. The role of emergency contraception. American Journal of Obstetrics and Gynecology 190: S40-38

13 World Health Organization, International Labor Organization. 2007. Post-Exposure Prophylaxis to Prevent HIV Infection: Joint WHO/ILO guidelines on post-exposure prophylaxis (PEP) to prevent HIV infection. HIV Programme. Geneva: WHO

14 Christian C, et al. 2000. Forensic evidence findings in prepubertal victims of sexual assault. Pediatrics 106: 100-04; Committee on Child Abuse and Neglect. "Guidelines for the evaluation of sexual abuse of children." Pediatrics 87.2 (199I): 254-260.
} 
Despite the availability of guidelines for managing child survivors of sexual violence (and the high proportion of such survivors presenting at police stations), recent findings ${ }^{15}$ highlight non-adherence to National Guidelines related to child survivors in police stations and health facilities. Specifically, police were found to be unaware of the National Guidelines and largely lacked the training to address child survivors' needs. Furthermore, the lack of transportation at police stations meant that child survivors' access to a range of health services was curtailed in this low-resource setting. In an earlier study, only $2 \%$ of survivors reporting to police stations were accompanied to the hospital by a police officer, as stipulated by the National Guidelines. ${ }^{16}$ Yet, survivors reporting to police stations are meant to be accompanied to the health facility by Victim Support Unit (VSU) police (police trained to care for sexual violence survivors) to ensure immediate access to comprehensive care and access to justice. At the health facility, VSU police are expected to take the child survivor's samples to the lab, and take statements from the attending health providers. These critical processes were not occurring, however, due to a lack of police transportation. With police unable to play these critical and mandated roles, few survivors can access comprehensive post-rape care.

This study therefore tested the feasibility of implementing new protocols to address these barriers in police stations, while supporting the implementation of the National Guidelines by VSU officers in both polices station and health facility contexts.

\section{Study Objective and Design}

The objective of this study was to assess the feasibility of implementing a transportation intervention within police stations, coupled with training and sensitization for police officers to perform their government-mandated roles in post-rape care. This intervention was developed as a means of enhancing children's access to comprehensive post-rape care in Zambia.

The study used an explanatory case study design, which "focuses on program implementation ... investigates how a program operates either at one or multiple sites [and] might ask questions such as, 'In early implementation of [a] ... program, what program aspects are working well or less well and why?"'17 The implementation of the National Guidelines by police and health providers in two police stations (Chawama and Kanyama police stations) and one hospital site (University Teaching Hospital [UTH]) was investigated as a single 'case.'

The two participating police stations are located in Lusaka Province and, since 2010, they have partnered with the Population Council in efforts to strengthen post-rape care services for survivors of sexual violence. As at 2013, the stations had an estimated combined catchment area population of

\footnotetext{
15 Chelwa et al. (forthcoming 2018). Formative evaluation of police station readiness for post-rape care service delivery in Zambia.

16 Mary Zama, Mardieh Dennis, Jessica Price, Stephanie Topp, Jonathan Kaunda Mwansa and jill Keesbury. 20I3. Mitigating the Consequences of Sexual Violence in Zambia by Decentralizing Emergency Medical Responses to Police Victim Support Units: Report on the Feasibility of Police Provision of Post-Exposure Prophylaxis for HIV (PEP) in Zambia. Lusaka: Population Council.

17 USAID (20/3). Technical Note on Evaluative Case Studies. https://usaidlearninglab.org/sites/default/files/resource/files/case_study_tech_note_final_2013_III5.pdf.
} 
296,000 inhabitants. ${ }^{18}$ This high population density was paralleled by high numbers of rape cases, which made both stations ideal candidates for the intervention.

Although the Chawama and Kanyama communities have Ist Level Hospitals, we found that these hospitals were only able to provide first aid and emergency care services in rape cases. For comprehensive medical care and forensic evidence collection, all rape cases were referred to UTH. Thus, UTH was the only hospital site included in the study.

This explanatory case study drew on qualitative and quantitative data-gathering techniques: semistructured, key informant interviews with VSU police (from the two police station sites), health providers (from UTH), and caregivers of child survivors presenting at police stations; fieldnotes of police observations as they accompanied child survivors and caregivers to UTH; and service statistics of the police-accompanied hospital visits.

Drawing on the case study approach, we assessed three dimensions of feasibility 19 :

- Acceptability: The extent to which the intervention for enhancing children's access to comprehensive post-rape care was judged as suitable, satisfying, or attractive to police, health providers, survivors, and/or their caregivers;

- Demand: The extent to which the intervention is likely to be used by police, health providers, child survivors, and their caregivers; and

- Implementation: The extent to which the intervention can be successfully delivered to children seeking post-rape services in the defined, but not fully controlled, contexts of police stations and health facilities in Zambia.

\section{Intervention Description}

The intervention consisted of three main components, namely:

I. Provider training and sensitization (February to April 2017);

2. Strengthening ECP provision at police stations (March to April 20I7) and

3. Strengthening transportation services at police stations (February to April 2017).

\section{Provider Training and Sensitization}

Two types of providers were involved in this component of the intervention: police at the two participating police stations, and post-rape care health providers at UTH, the only health facility offering comprehensive post-rape health care services in the vicinity of the two police stations.

A total of 12 VSU police officers and in-charges/department heads from the two police stations participated in a one-day sensitization session on the service delivery roles that the National Guidelines have assigned to VSU police in regard to child survivors presenting at police stations

\footnotetext{
18 Keesbury, Jill, Mary Zama, and Sudha Shreeniwas. 2009. "The Copperbelt Model of Integrated Care for Survivors of Rape and Defilement: Testing the feasibility of police provision of emergency contraceptive pills." Lusaka: Population Council.

19 Bowen, D.J. et al. 2009. How we design feasibility studies. American Journal of Preventive Medicine. 36(5): $452-457$
} 
(e.g., initial counseling, provision of ECPs, escorting child survivors to health facility points, and obtaining specific medical information from providers at these points).

In addition, three 4-day training sessions were held with VSU police and health providers. The topics covered during the training sessions included the National Guidelines, the medical effects of child sexual abuse, police provision of ECPs, forensic and medical considerations for sexual violence cases, and the multi-sectoral process established in the country for facilitating post-rape care (including the health, social service, and justice/legal sectors represented by UTH, Ministry of Gender, Young Women's Christian Association, the ZPS, the Legal Aid Clinic, and the police forensic lab). The sessions culminated in a visit to UTH's One-Stop Paediatric Centre, so that all trainees could familiarize themselves with the procedures involved in caring for child survivors.

Six health providers ( 2 providers each from UTH, Chawama Level I Hospital and Kanyama Level I Hospital) and 78 police officers ( 34 from Chawama, 40 from Kanyama, and 4 from other areas) were trained. Additionally, 5 supervisors of VSU officers in Kanyama and Chawama Police stations attended the training. A team of trainers from the Zambia Police Service, UTH Paediatric Centre of Excellence, the Ministry of Health, the Ministry of Gender, and the Population Council facilitated the 4-day session.

\section{Strengthening ECP Provision at Police Stations}

The intervention focused on working with Zambia Police Services and the Ministry of Health to ensure a regular and adequate supply of ECPs at the police stations, and also to hold a refresher training for VSU police on the provision of ECPs at their respective stations. Previous studies 20 have established the feasibility and effectiveness of police provision of ECPs to survivors presenting at police stations in Zambia, and this practice is embedded within the National Guidelines.

To strengthen the police provision of ECPs, we established sustainable channels for replenishment of the contraceptive by linking both police stations to the Zambia Police Sikanze Hospital in Lusaka. Police stations were issued with initial drug stocks for a month following training and were requested to follow up directly with this hospital in cases of stock-outs. To be eligible for police provision of ECPs, a female survivor had to be 10 years or older and had to have reported to the police station within 120 hours of the rape incident. A previous Council-led study that tested police provision of ECPs involved consultation with a wide range of stakeholders (nearly 50), including the Zambian Ministry of Health, Ministry of Home Affairs, Ministry of Community Development and Social Services, and various non-governmental organizations and churches.21 Given the sensitivity of having trained police provide ECPs to survivors, this group of stakeholders decided that survivors no less than that age of 10 should be allowed to participate in the study. In addition, the majority of survivors presenting below the age of 10 were considered to be less likely to have begun menstruating. The age range of 10 years and above was selected for the current study for the same reasons.

During the period of the intervention, a refresher training on ECP provision to survivors by police in police stations was held at the Zambia Police Hospital with all VSU Officers from the two participating police stations.

20 Keesbury Jill, Mary Zama, and Sudha Shreeniwas. 2009. "The Copperbelt Model of integrated care for survivors of Rape and Defilement: Testing the feasibility of Police provision of emergency contraceptive pills." Lusaka: Population Council.

21 lbid. 


\section{Strengthening Transportation Services at Police Stations}

As part of the intervention, transportation services at the two police stations were strengthened in the following ways: the Population Council worked with the Police Officers in Charge at the police stations to identify a taxi service to transport child survivors, their caregivers, and a VSU police officer to UTH, as stipulated in the National Guidelines, at an agreed-upon rate and on a monthly payment schedule. Child survivors in need of post-rape care (and their caregivers, if applicable) were transported to UTH via this service in the company of a VSU officer. The role of VSU officers at the hospital was to enhance child survivors' access to post-rape care, and to ensure positive legal outcomes for those caregivers/children who wanted to take legal action. As mentioned previously, these VSU officers were sensitized on the roles assigned to them in the National Guidelines to increase survivors' access, such as escorting child survivors to a health facility, ensuring the child survivor receives immediate attention at the health facility by liaising with health providers, taking the child survivor's samples to the lab, collecting the lab results, and taking statements from the attending health providers. At the end of child survivors' hospital visits, the taxi service transported the police, the survivor, and the caregiver back to the police station.

\section{Data Collection}

Data collection took place from March to April 2017 and involved key informant interviews with caregivers of child survivors, as well as with VSU police officers and health providers who participated in the provider training sessions; fieldnotes recorded by VSU police officers who attended to child survivors during the intervention period; and service statistics of child survivor cases that were documented in the fieldnotes.

Two different field guides - one for caregivers, and one for providers - facilitated the collection of key informant interview data. The field guide for caregivers was translated into the local languages (Nyanja and Bemba). Five police officers and two [2] Population Council research assistants participated in a 2-day data collection training session. In addition to sensitization around sexual violence, the session focused on the project goals, the study tool content, data collection modalities, and ethics in research.

The study received ethical and research clearance from the Institutional Review Boards of the Population Council in New York and of ERES Converge in Lusaka. In addition, research clearance was obtained from ZPS and the National Health Authority. Prior to conducting the key informant interviews, written, informed content was obtained from the respondents concerned.

Police and health providers were eligible to participate in the study if they were involved in providing post-rape care services to children, and if they had participated in the provider training and sensitization sessions mentioned above. The eligibility of caregivers to participate in the study was based on their having accompanied a child survivor of rape to one of the participating police station sites for support.

\section{Key Informant Interviews}

Audiotaped key informant interviews were used to gain an understanding of the challenges and successes that the intervention was experiencing from the perspectives of various stakeholders: caregivers of child survivors, and police and health providers meant to facilitate children's access to 
post-rape care services. A total of 22 stakeholders were interviewed - 12 caregivers, 7 VSU officers from the police station sites, and 3 health providers - one each from UTH, Chawama Hospital, and Kanyama Hospital.22

\section{Field Notes}

Fieldnotes were documented to capture a number of specific topics: VSU officers' observations of processes that went well/wrong while post-rape care was sought by survivors; observations of issues that were satisfying/dissatisfying to child survivors and caregivers in the process of seeking post-rape care; and verbatim quotes from conversations that are relevant to the study. Fieldnotes were handrecorded for a total of $2 \mathrm{I}$ child survivors who reported to the police stations with a caregiver and were accompanied by VSU officers to UTH during the intervention period.

\section{Service Statistics}

The National Guidelines outline four key roles assigned to VSU police officers when they accompany child survivors to a health facility for medical care: I) ensuring the child survivor receives immediate medical attention, 2) taking the child survivor's samples to the lab, 3) collecting the results of the lab testing, and 4) taking statements from the attending health providers. Service statistics were teased out from the fieldnotes and collated to capture information on the proportions of child survivors receiving these four components of care from VSU police officers at UTH.

\section{Data Processing and Analysis}

The key informant interviews were audiotaped and conducted by trained research assistants. The fieldnotes were hand-recorded by trained VSU officers who were involved in accompanying child survivors from the police station to UTH. Interview and fieldnote transcripts were later typed up in MSWord by the research assistants and VSU officers, respectively.

A two-stage approach was employed for analyzing the qualitative data. The first stage involved the review and examination of all transcripts (key informant interviews and fieldnotes) for critical themes and trends with regard to the domains of feasibility that the study aimed to assess - namely, acceptability, demand, and implementation - from the perspective of child survivors, caregivers, and VSU police officers and health providers who had received training under the intervention. The second stage entailed teasing out key programming messages in regard to the intervention, based on the major themes around the domains of intervention acceptability, demand, and implementation. Service statistics related to post-rape care were abstracted from the fieldnotes, and the numbers of child survivors receiving specific forms of support which (according to the National Guidelines) are meant to be facilitated by VSU police officers, were documented manually.

\footnotetext{
22 Although Chawama and Kanyama Hospitals did not serve as health facility sites in this study, providers from these settings were included in the training sessions at the request of the Ministry of Health.
} 


\section{Key Findings}

Training/sensitization on the National Guidelines promoted intra- and inter-sectoral action

Key informant interview data showed evidence of a series of positive actions within the police stations, within health facility contexts, and between police and health sectors. The various actions were specifically informed by the training that police and health providers received on the National Guidelines. Health providers and police alike pointed out that the National Guidelines' step-by-step instructions were particularly helpful because they served as a checklist, ensuring that providers no longer omitted key aspects of the response to survivors. As a healthcare provider explained:

"Before, we were skipping a lot of important steps...With the document, we've realized the importance of the evidence, how to collect it, how to counsel survivors properly.... The [National Guidelines] book has helped me polish these skills." (Health provider, UTH)

Knowledge of the Guidelines also helped police officers enrich their practice by incorporating crisis counseling into their survivor intake processes, as mandated by the Guidelines. Some spoke of reordering their tasks by providing such counseling to child survivors ever before issuing a police medical report form, as prescribed by the Guidelines:

"Before, we would issue the police medical report form to the survivor and wait till it was signed to record or get the full story of what had happened. Now, we are able to get the full story through crisis counselling." (Chawama Police Station)

In other words, police were more prone to listen to child survivors as a result of the training, and crisis counseling provided an opportunity for them to do so. It also facilitated comprehensive documentation of the rape incidents and gave an understanding of the kind of support needed by child survivors before police medical reports were returned.

The training helped providers revise their overall approach to sexual violence cases. A police officer recalled the conventional approach to such cases: "Before, we even used to chase [sexual violence survivors] away and say that, 'This is a civil case, so just go resolve it back home."' (Kanyama Police Station) Caregivers corroborated this change in approach. As one explained:

"Some time back, when a child is defiled, people could only discuss it among themselves...they would just bathe the child and forget about it. But this time, we were even advised [by the police] to go to UTH and have the child tested." (Kanyama Police Station)

As a result of the training on the National Guidelines, the mandated roles of police officers with regard to child sexual violence cases became better known, and this helped VSU officers carry out their duties with ease:

"Even our in-charge now understands that when I'm escorting a survivor of sexual violence...it's actually [part of my job] - something the government wants me to do as a VSU officer." (Chawama Police Station)

Additionally, the National Guidelines began to serve as a clarifying document in the daily work of health providers, police, and those in the legal sector: 
"I remember a situation where we had a disagreement with the police on how to approach or deal with these cases. Luckily, we had the Guidelines, so we opened it up to the exact section and it was a done deal." (Health provider, UTH).

Similarly, a police officer recalled an instance where he used the Guidelines to justify his actions when they were called into question:

"Once in court, the judge asked me why I was escorting the survivor to UTH and said that maybe I did something [wrong] along the way," he said. "I responded that I was mandated by the law and referred to the National Guidelines, since it gives me the authority to escort survivors to the hospital for medical examination." (Chawama Police Station)

The improved inter-sectoral action and cooperation was also observed by caregivers. In the words of one caregiver: "I also liked the fact that the police worked together with the medical personnel to ensure that my child obtained the best service."(Caregiver of 14 year old survivor, Kanyama)

The training did more than just improve providers' knowledge of the National Guidelines and spur action accordingly. Interviews with caregivers suggest that it also improved the approach of VSU police and health providers to child survivors and caregivers. Caregivers particularly expressed appreciation for the police's objectivity, professionalism, and their ability to provide privacy:

"I was so very happy about the way the police attended to us... because they did not look at who I am, the way I was looking, dirty or clean or what, but in my poverty they looked at me and helped me so much." (Caregiver of 14 year old survivor, Kanyama)

"For those of us who live in these compounds, it's sad and embarrassing once others discover that your child has been raped. They begin to gossip that it's this woman's daughter who was defiled and so forth ... [but] even the people in our neighborhood are not aware of what happened to my daughter."(Caregiver of 15 year old survivor, Kanyama)

"It is the first time in Zambia to see the police helping us like they did for us ... I am still surprised that I received that kind of assistance from the police and UTH. (Caregiver of 15 year old survivor, Kanyama)

Transportation was seen as critical for improving child survivors' access to care

The transportation component of the intervention was embraced by the vast majority of survivors and caregivers. During the intervention period, $2 \mathrm{I}$ rape survivors reported to the police stations. Of these, 19 were accompanied to UTH by a police officer. The caregivers of the only two survivors who were not escorted did not wish to be. Only one caregiver who was escorted expressed discomfort with this service. As she explained, "Whoever will see you with the police will tend to think you are a criminal and so I didn't feel very comfortable being with the police for long" (Caregiver of 15 year old survivor, Kanyama). Despite this, she appreciated the police's help and said, "If the police officer was not with us, we wouldn't have had the help that our child [received]." 
Caregivers, police and healthcare providers alike appreciated the transportation and recommended that it be provided for all future sexual violence cases. The novelty of transportation led some caregivers to express shock when it was offered:

"I wasn't very sure when they told me the police officer will escort me to UTH because these days everything is corruption. When he did, I was really very happy."(Caregiver of 12 year old survivor, Chawama)

Others were pleased that the transport covered the round trip to UTH:

"I'm grateful for everything the police did for us...especially the way they assisted us with transport. [On the way back], they didn't drop us off somewhere in town but brought us back to the police station." (Caregiver of I4 year old survivor, Kanyama)

Beyond the convenience that transportation offered to child survivors, caregivers and providers highlighted the formidable barrier that the lack of transportation poses for child survivors' access to comprehensive care. Many caregivers (7 out of the 12 interviewed) spontaneously indicated that transportation was an important part of the process of obtaining comprehensive care. Out of the 12 caregivers that participated in the key informant interviews, about half $(n=5)$ admitted to not having sufficient funds to get to UTH on their own. As one caregiver put it:

"I really liked the transport they provided for us to go to UTH. If you have no transport, you keep postponing taking the child to the hospital. With transport, it was much easier for us to go to UTH. We didn't pay anything for the services rendered to us; everything was free." (Caregiver of I4 year old survivor, Kanyama)

VSU police officers and health providers also viewed transportation is crucial for improving access to services:

"We never used to have transport and when a case was reported, we would say, 'When you have money tomorrow or the day after, you can go to UTH - that's where you'll be attended to,' and the survivors never used to go." (Kanyama Police Station)

"Transport is where we lose the most patients as transport is the excuse most patients give [for not seeking services]. ... I would recommend a system where transport is provided immediately so that evidence is collected the very day the case is reported." (Health provider, UTH).

"There should be permanent transport... as of now, we don't have transport that can be relied upon." (Kanyama Police Station)

"The most important thing I can recommend is that the VSU department should have its own vehicle." (Kanyama Police Station)

"Each station and police post should have vehicles dedicated for GBV cases involving children." (Chawama Police Station) 
Police accompaniment eased the health facility encounter for child survivors and caregivers

Key informant interview data show that caregivers viewed the police as not only guides, but also as advocates. This advocacy role was perceived to hasten service delivery at UTH and to boost the confidence of caregivers in the process of service-seeking for child survivors. Being accompanied by the police simplified and expedited what used to be a long and confusing process for child survivors and caregivers:

"I was happy because the police officer was speaking on our behalf to the medical practitioners... which made the process faster."(Caregiver of 13 year old survivor, Kanyama)

"If one goes alone to UTH, they may not be attended to accordingly, but with the police, things move faster." (Caregiver of I 4 year old survivor, Kanyama)

"If I went there alone, I wouldn't have the confidence to go inside and begin speaking for myself, but because we went with a government representative, we just went straight to the offices without having to wait outside." (Caregiver of I4 year old survivor, Kanyama)

"We were accompanied by the police officer from one point to another and he would only remain outside when we were being attended to by the Doctor and he would only come in when called upon. It is very important for us to be accompanied by the Police Officers because we never felt lonely because we had a shoulder to lean on........ on this day we were assisted well and we were not depressed. The Police officer kept encouraging us....." (Caregiver of 4 year old survivor, Chawama)

"The Police officer was with us as we went through stage by stage of the all process. So it was easy for us to complete the procedure" (Caregiver of 16 year old Survivor, Chawama)

Nonetheless, the guidance role played by police at UTH was also regarded by caregivers as important. Not knowing where to go within a large, public health facility such as UTH can serve as a barrier in itself, as some caregivers intimated:

"If I went alone, things would have been much more difficult. I was very happy because we had the police officer who helped us all the way until we came back and am still thankful that the police helped us so much by showing us where to go and what to do." (Caregiver of 15 year old survivor, Kanyama)

"[When we brought a survivor to UTH on our own], we were being turned away from office to office, so we gave up and did not follow up on the case." (Caregiver of 13 year old survivor, Chawama)

"If I had no Police escort I wasn't even going to know where to go and I wouldn't have even gone there because I wouldn't have known where to start from because UTH is quite big." (Caregiver of 12 year old Survivor, Chawama)

The caregiver who mentioned being turned away above, later presented with the child survivor at Chawama Police Station during the intervention period. As a result, she was accompanied to UTH by 
a VSU officer and reported having much easier access to services as she and the child survivor were being "escorted from place to place."

From the perspective of caregivers, the presence of police also ensured that key regulations within the National Guidelines were followed, such as that of survivors receiving health services for free. Several caregivers had prior experience of seeking post-rape care services and of having to pay certain fees. During the intervention period, however, they observed a marked change:

"Before, whenever we reported such cases to the police station, the police officers only issued us with a medical report and asked us to go to the hospital where a doctor would sign on the form for a $\mathrm{k} 50$ fee...but now, things have been made easier since the police are accompanying us to the hospital and guiding us at each and every service point." (Caregiver of 13 year old survivor, Kanyama)

"Now [the police] are guiding us on all steps that we need to pass through without paying anything. Even the medicine was given for free. For me, this shows that things have improved." (Caregiver of 14 year old survivor, Kanyama)

However, field note data indicates that some child survivors/caregivers did incur some costs in the process of accessing post-rape care services during the intervention period. Specifically, a number of caregivers were instructed to make photocopies of forms required for post-rape care:

"Mwape [not her real name], a 16 year old survivor, was taken to UTH at 12 PM. At the UTH police post [within the UTH One-Stop Center], Mwape's mother was asked to photocopy forms, which are supposed to be free." (Fieldnote excerpt, documented by VSU police officer, Chawama)

"At the [UTH] police post, Kisani's mother was asked to make photocopies of some forms. 'You said the whole process was supposed to be free, but photocopying these forms is like paying for them,' she told the escorting police officer. Kisani, a six year old survivor, was examined and she and her mother received counseling." (Fieldnote excerpt, documented by VSU police officer, Kanyama)

Police respondents also pointed out how they were able to collect evidence more efficiently as a result of having to accompany survivors to UTH right away. As one police officer said, "Escorting survivors to UTH helps us secure evidence immediately... if the survivor reports to UTH after 4 days, most of the evidence has been destroyed." (Chawama Police Station)

For police officers, escorting survivors was also beneficial from the perspective of rapport-building. In the words of one VSU officer: "In the past, we could only spend maybe 5 minutes with the survivor, but now that we escort them, we have more time to get to know them and they open up." (Kanyama Police Station)

The National Guidelines require revisions to align with the changing landscape of post-rape care service delivery

Study findings revealed a changing landscape in post-rape care service delivery that the National Guidelines (published in 20II) have not necessarily kept abreast of. With regard to ECPs, for example, the Guidelines prescribe the provision of this contraceptive to eligible survivors at police stations. The rationale for this is that many survivors might not present at UTH after reporting at police stations, 
and so the provision of ECPs by police could help mitigate unintended pregnancy. However, fieldnote data from the study show that while 18 out of 21 child survivors presenting at police stations were eligible to receive ECPs in these settings ${ }^{23}$, only 4 received it at participating police stations. Interviews with VSU officers revealed that ECPs were not provided in all eligible cases because the VSU police officers planned to escort survivors to a health facility, where ECPs could be provided along with a comprehensive package of medical services. Yet, our study findings also point to barriers within UTH (described in the next section of this report) that could hinder the uptake of post-rape care services by survivors, including ECPs. Thus, in implementing the current intervention further, it would be important to emphasize to VSU police the need for immediate provision of ECPs to eligible providers at the police station even if further care will be sought at a health facility.

Further, the National Guidelines outline several roles for VSU police officers when they accompany child survivors to a health facility for medical care, including taking the child survivor's samples to the lab and collecting the results of the lab testing. However, fieldnote data demonstrate that child survivor samples were taken to the lab on only a few occasions because the vast majority of child survivors presenting at police stations during the study period were below the age of I6. The Pediatric Center at UTH also serves as a One Stop Center. It caters specifically to child survivors of rape below the age of 16, thus rendering redundant some of the police roles outlined in the National Guidelines. For instance, survivor samples are handled completely by UTH's One Stop Center for children below age 16, particularly as this One Stop Center employs 2 of its own VSU police officers. With the current proliferation of one stop centers in Zambia, the National Guidelines now need to take into account what this means for the role of VSU officers within such Centers, versus their role in regular health facility settings. Also to be considered is the fact that regular health facility centers do not have the capacity to offer comprehensive SGBV services.

\section{Post-rape care service delivery in health facilities must be strengthened for greater efficiency of multi-sectoral interventions}

Despite the mostly positive feedback about the intervention on the part of various stakeholders (caregivers of child survivors, VSU police officers, and health providers), the model is not without its challenges. Unsurprisingly, many of the challenges stemmed from the health facility site, which received the least inputs under the intervention. The challenges revolved around three main areas: lengthy wait times at the health facility site, understaffing at both the health facility and police station sites, and undersupply of forms related to post-rape care at the health facility site.

\section{Lengthy wait times}

Additional roles outlined for VSU police accompanying child survivors to health facilities include ensuring the child survivor receives immediate medical attention, and taking statements from the attending health providers. Although many caregivers indicated that police presence ensured the expediting of post-rape care service delivery, interviews with VSU police officers demonstrated that this did not occur consistently. Due to various constraints, police were not always able to ensure that child survivors received immediate care once they got to the health facility.

${ }^{23}$ Out of the 21 child survivors, 2 were girls under age of I0, and I was a boy. Consequently, only a total of 18 were eligible to receive ECPs under the study. 
Fieldnotes indicate that in one case, a police officer escorted a survivor to UTH at 12:00 hours and was only able to leave at midnight. As one police officer explained, "The process at UTH is very slow. One could go at 16:00 hours and come back around midnight or even 03:00 hours." According to another police officer, caregivers and survivors "are made to wait for long periods of time and some even opt to go back home before they are seen." To prevent this, he suggested improving the waiting areas by providing entertainment and refreshments. This strategy seemed to be successful in at least one case documented in the fieldnotes, as observed below:

"At UTH, Fanny (a 6 year old survivor) had to wait 2 hours to be seen. The escorting police officer said, 'It seemed as if the hospital staff did not pay attention to our case.' She was counseled and examined by a doctor. After the examination, she was happy because she had been given jiggies and a drink. Her mother said, 'Now this is the way she is at home. She talks a lot."”

These lengthy wait times also affect the timeframe in which survivors are given care. In three cases, survivors reported to the police station in the afternoon and were told to come back the following day as it was too late to attempt to go to UTH. One police officer noted, "Cases reported [to UTH] after 14:00 hours are not usually attended to the same day." Fieldnote data from the study highlight a case in which the VSU police officer did not take a statement from the attending health provider because the lab results were not returned expeditiously, and the police officer expected to take the provider's statement after receiving the lab results.

VSU police officers also noted that lengthy wait times at the health facility meant being away from the police station, which in turn, meant not being able to provide support to other survivors presenting at the station. Furthermore, the escorting officers were sometimes subject to suspicion when they were gone for long periods of time: "Other police officers from other departments begin to complain, thinking maybe you are just doing your own business, not knowing that you are actually helping the survivors," one police officer from Chawama said.

\section{Understaffing}

The lengthy wait times described in this report were largely attributed to an inadequate number of providers at UTH. As one police officer explained:

"When there is only one doctor available, survivors are made to wait for long, which is not supposed to be the case, since these cases are to be regarded as emergencies.

There should be more doctors attending to survivors." (Police Officer, Chawama)

Another police officer noted the importance of increasing the number of doctors at UTH, as this affects the time taken to prosecute a case. "We wait up to 2-3 weeks for the medical report forms to come back. If they have more doctors, it will help.” (Police Officer, Chawama)

Moreover, police officers themselves recognized there were gaps in their own provision of care. The lack of staff was continually cited as an area of improvement by police and healthcare providers alike. At UTH, the lack of VSU officers caused inconveniences for survivors and their escorting police officers. "The VSU officer who was supposed to be on duty [at the UTH One Stop Center] wasn't there, so we walked all the way to the Casualty Department. It would be better if there are 2-3 officers at the post," one police officer from Chawama said. 
Police officers serving at stations also expressed concerns about being understaffed. One police officer noted, "If the only VSU officer at the station escorts a survivor to UTH, the office will remain closed, meaning that any other survivors [that] come after will not be attended to." (Police Officer, Kanyama)

The lack of personnel at the police stations was particularly felt during nighttime and weekend hours. Although both police stations provided post-rape care services through the Victim Support Unit during the week, between the hours of 8:00 to 17:00 hours, they were closed or operated on limited hours during the weekend. While Chawama's VSU office was open from 8:00 to 14:00 hours on weekends, Kanyama's VSU office was closed and survivors were attended to by the front office staff. This creates missed opportunities for providing child survivors with post-rape care since, as one police officer stated, "Most of these cases occur at night and are sometimes reported at night." (Police Officer, Kanyama)

In practice, however, police officers felt that their peers at UTH caused delays in the prosecution of cases. A police officer from one of the stations explained, "VSUs at UTH delay in delivering the medical report forms...so we end up over-detaining the suspects... we have to wait for the medical report forms to be signed and delivered, and that's when we can continue acting on the case." (Police Officer, Kanyama). To prevent this, another police officer suggested increasing the number of VSU officers stationed at UTH.

Healthcare providers recommended increasing the number of officers as well: "It would be helpful if the number of officers, especially female ones, increased, and if they were trained in counseling," one said. Police officers also felt they could benefit from training in counseling. "VSU police officers should undergo full-time courses on how to handle survivors of GBV... officers should know how to handle the trauma the survivor is going through," one police officer from Chawama said.

\section{Undersupply of forms related to post-rape care}

The undersupply of forms related to post-rape care was a noted barrier within the health facility site. In II out of the 19 cases that were escorted to UTH during the intervention period, the child survivor was referred to another department before s/he was able to receive care at the Pediatric One-Stop Center. Escorting police officers described their experiences:

"The survivor was 12 years old, so she should have been able to receive services at the One-Stop Centre. We went directly there, but because they had no forms, we had to go to [another department] to open a file...UTH is big, so the survivor complained when that happened. It is no longer a One-Stop Centre if survivors are referred to Casualty and other clinics." (Police Officer, Kanyama)

"Survivors and caregivers are forced to run around and make photocopies, which is not supposed to be the case. The post should be stocked so survivors are not paying for photocopies." (Police Officer, Chawama) 


\section{Conclusion and Recommendations}

The objective of this study was to assess the feasibility of implementing a transportation intervention within police stations, coupled with training and sensitization for police officers to perform their government-mandated roles in post-rape care. This intervention was developed as a means of enhancing children's access to comprehensive post-rape care in Zambia.

Three dimensions of feasibility were assessed in this study, namely: acceptability, demand, and implementation. The study findings demonstrate that the overall intervention was highly acceptable to participants: police and health providers found great value in the training and sensitization sessions on the National Guidelines and on the management of child survivors, and drew on knowledge gained from these sessions to revise and strengthen their practice, resolve inter-sectoral bottlenecks, and disseminate information within and across SGBV response sectors. Caregivers noted positive changes in the practice of police, expressed high satisfaction with the transportation and police accompaniment components of the intervention, and indicated that access to post-rape care would have been limited without this support.

Findings from the study also suggest that there is a high level of demand for the intervention, as evidenced by the fact that almost all caregivers ( 19 out of 21 ) opted to use the transportation and police accompaniment support provided to ensure that child survivors received immediate medical care. Further, a repeated recommendation from police following the intervention had to do with ensuring that police stations have dedicated transportation to support survivors.

Findings on implementation - i.e., the extent to which the intervention can be successfully delivered in police station and health facility contexts in Zambia - demonstrate that the training/sensitization, transportation, and police accompaniment aspects of the intervention can be delivered quite successfully. The package of interventions helped ensure that almost all survivors presenting at the police stations and willing to be accompanied by police during the study period made it to a health facility. Of these, all but one received same-day care. Nonetheless, the intervention process highlighted the challenges found within health facility settings themselves, and underscored that successful delivery of this intervention in the long-term is dependent on ensuring that service delivery with health facility contexts is strengthened as well.

Based on the aspects of feasibility under investigation in this study, we conclude that it is feasible to implement a package of interventions involving police and health provider training/sensitization and the introduction of transportation for child survivors within police stations. This package of interventions enhances child survivors' access to comprehensive post-rape care.

A series of recommendations are provided below to help support the operationalization and sustainability of the intervention:

I. Sensitize providers to their roles in the National Guidelines: Incorporate National Guidelines sensitization into police, health, and legal pre-service and in-service training at all levels.

2. Build the capacity of providers: Develop and implement training curricula for police, health, and legal providers, drawing specifically on the National Guidelines to ensure that 
providers are equipped to play their mandated roles. This training should also be integrated into pre-service and in-service training for the various sectors.

3. Experiment with transport facilitation models for Victim Support Units: Given the importance of transportation for the success of this intervention, innovating with affordable transportation models would be important to identify cost-effective options. Possible models could include the development and use of public transportation stipends, and the provision of motorized rickshaws.

4. Update National Guidelines: Review the National Guidelines to update guidance on provider roles (police, health, legal) to facilitate a multi-sectoral response in both One-Stop Centers (OSCs) and non-OSCs.

5. Strengthen health facilities: Prepare health facilities (OSCs and non-OSCs) to promote an effective multi-sectoral response by addressing understaffing and ensuring administrative costs (e.g., costs of photocopying) are not borne by survivors. 


\section{Appendices}

\section{Appendix A: Interview Forms}

\section{INTERVIEW WITH PROVIDERS}

Name of Interviewee:

Location:

Research Assistant:

Date:

I. [Show respondent a copy of the national guidelines]: Have you seen this document before? What is it, and in what ways do you use it in your daily work, if at all?

a. In what ways has your work as a [VSU officer/health provider] been impacted, if at all, by this document? Kindly elaborate.

b. In what ways has it facilitated your work as a [VSU officer/health provider]? Please elaborate and provide an example of what you mean.

c. In what ways has it obstructed your work as a [VSU officer/health provider]? Please elaborate and provide an example of what you mean.

d. What impact, if any, would you say this document has had on your overall department, whether positive or negative? Please say more about that.

2. Tell me what you know about the referral process from police stations for children/adolescents who come to UTH for post-rape care. From what you have observed, in what ways has this process changed recently, if at all?

a. Let's start by discussing the positive changes, if any. Kindly elaborate.

b. What about negative changes, if any? Kindly elaborate.

c. What, if anything, would you recommend for improving the referral process from police stations for children/adolescents who come here for post-rape care?

3. Now, let's talk a bit about the role of Victim Support Unit (VSU) police in post-rape care at UTH.

a. How would you describe their role?

b. What functions does a VSU officer play in post-rape care at UTH on a day-to-day basis, from your observation?

c. In what ways have these roles been useful, from your observation? Kindly elaborate with an example.

d. In what ways have these roles been obstructive or unhelpful, from your observation? Kindly elaborate with an example.

e. What, if anything, would you recommend in order for the role of VSU officers to be improved at UTH? Please say more about that. 
4. Remember, my main interest has been to figure out how feasible it is for children/adolescents to obtain a full package of post-rape care services by the time they have gone to both the police and UTH.

a. Given this interest, and given what you know about how things are working, what do you feel I should have asked about that I did not ask you today? l'll let you think about this for a minute. [Have them respond to any question they raise].

b. Is there anything else that's important for me to know about how post-rape care for children/adolescents is functioning at the police station or UTH?

\section{INTERVIEW WITH CAREGIVERS}

Interviewee's unique identifier/age (do not write name):

Location:

Research Assistant:

Date:

I. I would like to take you back to the first time you brought your child to the police station. From the police station, your child was referred to UTH. Tell me how your child got to UTH. Walk me through the process, step-by-step.

a. After you got to UTH, how did you and your child know where to go, and what to do when you got there?

b. In what way were the police involved in this process, if at all?

c. How easy or difficult would you say it was to know where to go next at UTH, and what to do when you got there? Kindly elaborate.

d. What did you like about the process of getting your child from one service point to another at UTH, and why?

e. What did you dislike about the process of getting your child from one service point to another at UTH, and why?

2. Do you recall being accompanied from one point to another (by anyone from the police) as you sought services for your child at UTH?

a. [If yes:] How important would you say it is for caregivers and their children to be accompanied in that way when they seek services at UTH? Kindly elaborate.

3. Was your child referred to anywhere outside the hospital to get any further services (e.g., shelter, support group, etc.)?

a. [If yes:] Where was your child asked to go?

b. Did your child ever get there? If not: What is the reason why s/he never got there?

C. If they did get there: Did you accompany her/him? 
d. [If applicable:] Describe to me how s/he got there.

e. What made it easy for him/her to get there?

f. What made it difficult for him/her to get there?

4. [If applicable:] Overall, how happy would you say you were with the kind of support you received from police on the day your child visited UTH? Kindly elaborate.

5. My main interest has been to figure out how to make it easier for children and young people to receive all the post-rape care services they need by the time they have gone to both the police and UTH. Given this interest, and given what you know about how things are working at the police stations and at UTH, what do you feel I should have asked about that I did not ask you today? l'll let you think about this for a minute. [Have them respond to any question they raise].

c. Is there anything else that's important for me to know about how post-rape care for children/adolescents is functioning at the police station or UTH? 
Appendix B: Case Log-Narration of survivor experiences

These narratives are derived from the field notes that police officers kept during the intervention.

\begin{tabular}{|c|c|c|c|c|}
\hline Case & Age & The Incident & Access to and Experience at VSU & Referral to and Experience at UTH \\
\hline \multirow[t]{2}{*}{$\begin{array}{c}\text { I } \\
\text { "Mwape" }\end{array}$} & \multirow[t]{2}{*}{16} & $\begin{array}{l}\text { Mwape used to sleep in the sitting room at her house. } \\
\text { One day, she dreamed that her step-father wanted to } \\
\text { sleep with her and woke up to discover that it was real. } \\
\text { She said, "I tried to scream but he held my mouth and } \\
\text { forced himself on me and raped me." The next morning, } \\
\text { she told her grandmother, "I have stopped sleeping in the } \\
\text { sitting room because my step-father raped me." Mwape's } \\
\text { mother overheard her and brought her to the police } \\
\text { station. }\end{array}$ & $\begin{array}{l}\text { The VSU officer on duty asked Mwape if she } \\
\text { was comfortable with who was in the room. } \\
\text { Mwape requested to be interviewed alone } \\
\text { and the VSU officer respectfully asked the } \\
\text { mother to leave. After that, Mwape freely } \\
\text { answered all the questions but appeared to } \\
\text { be traumatized. She was escorted to the } \\
\text { police station by the VSU officer. }\end{array}$ & $\begin{array}{l}\text { Mwape was taken to UTH at I2 PM. At the } \\
\text { UTH police post, Mwape's mother was asked } \\
\text { to photocopy forms which are supposed to } \\
\text { be free. Since there was only I doctor on } \\
\text { duty, Mwape had to wait till } 23: 30 \text { to be seen, } \\
\text { a full II.5 hours after she arrived. }\end{array}$ \\
\hline & & \multicolumn{3}{|c|}{\begin{tabular}{|l} 
Follow up: Mwape's step-father committed suicide a month later. The case will not go anywhere and it's likely that she will be blamed for his suicide. \\
\end{tabular}} \\
\hline \multirow[t]{2}{*}{$\begin{array}{c}2 \\
\text { "Bupe" }\end{array}$} & \multirow[t]{2}{*}{15} & $\begin{array}{l}\text { Bupe used to live alone with her biological father. He would } \\
\text { give her hard jobs to perform and if she didn't do them } \\
\text { well, he would beat her and rape her. One day, Bupe's } \\
\text { neighbor noticed that she was crying and asked her what } \\
\text { had happened. Bupe explained and said, "I wish I could go } \\
\text { stay with my mother but I don't know where she lives." } \\
\text { The neighbors found her mother and brought Bupe, her } \\
\text { mother and father to the station. }\end{array}$ & $\begin{array}{l}\text { Bupe was hesitant to talk and would cry as } \\
\text { she explained what had happened. She also } \\
\text { asked to be kept hidden from her father, who } \\
\text { was detained in a police cell, because she was } \\
\text { afraid he would beat her. Eventually, Bupe } \\
\text { revealed that the abuse had been happening } \\
\text { for two years. The VSU officer issued a police } \\
\text { medical report and escorted Bupe and her } \\
\text { mother to UTH. }\end{array}$ & $\begin{array}{l}\text { When they arrived at UTH, the VSU officel } \\
\text { overheard Bupe saying to her mother, "I don' } \\
\text { know what will happen here. We are sc } \\
\text { dirty... they will know we are from } \\
\text { compound," to her mother. At the One-Stop } \\
\text { Centre at the Paediatric Centre fo } \\
\text { Excellence, they were told that the doctor } \\
\text { were off-duty and were advised to go tc } \\
\text { another department or come back anothe } \\
\text { day. The mother was unhappy and said she di } \\
\text { not have the transport fare to go back the nex } \\
\text { day. }\end{array}$ \\
\hline & & \multicolumn{3}{|c|}{ Follow up: Bupe and her mother returned to UTH 2 days later on their own. } \\
\hline $\begin{array}{c}3 \\
\text { "Chisenga" }\end{array}$ & 16 & $\begin{array}{l}\text { Chisenga and her friend (also a survivor) were out one } \\
\text { evening when they met two men who asked them to hang } \\
\text { out. "They gave me a Fanta," she said. Later, a group of } \\
\text { people came across an unfinished house. They went in and } \\
\text { found Chisenga and her friend being raped by two men. }\end{array}$ & $\begin{array}{l}\text { When Chisenga arrived at the station, she } \\
\text { was visibly drunk and was vomiting. She slept } \\
\text { in a corridor at the police station and the next } \\
\text { morning, her mother came to the police } \\
\text { station. "You remember the last time I came?" }\end{array}$ & $\mathrm{n} / \mathrm{a}$ \\
\hline
\end{tabular}




\begin{tabular}{|c|c|c|c|c|}
\hline Case & Age & The Incident & Access to and Experience at VSU & Referral to and Experience at UTH \\
\hline & & $\begin{array}{l}\text { The good samaritans brought Chisenga, her friend, and one } \\
\text { of the assailants to the police station at midnight. }\end{array}$ & $\begin{array}{l}\text { her mother said to the VSU officer. "She isn't } \\
\text { changing. Just kill her so that I can rest." The } \\
\text { VSU officer offered to escort Chisenga and } \\
\text { her mother to UTH but Chisenga's mother } \\
\text { refused. }\end{array}$ & \\
\hline $\begin{array}{c}4 \\
\text { "Diana" }\end{array}$ & 15 & $\begin{array}{l}\text { Diana was raped in the same situation as Chisenga. She } \\
\text { described the same story as Chisenga. }\end{array}$ & $\begin{array}{l}\text { Diana was also very drunk when she came to } \\
\text { the police station and she also slept in a } \\
\text { corridor at the police station. In the morning, } \\
\text { her step-mother came to the police station } \\
\text { and started shouting at her. "Just beat her so } \\
\text { that she stops being a prostitute. My daughter } \\
\text { is the problem," she said. Diana was very } \\
\text { angry and said, "leave the perpetrator, he's } \\
\text { innocent. I started having sex when I was } 9 \\
\text { years old. My step-father used to rape me and } \\
\text { give me K } 50 \text { to shut up. I told my mother but } \\
\text { she said I should just keep quiet." The VSU } \\
\text { officer offered to escort Diana and her step- } \\
\text { mother to UTH but her step-mother refused, } \\
\text { saying it was a waste of time. }\end{array}$ & $\mathrm{n} / \mathrm{a}$ \\
\hline $\begin{array}{c}5 \\
\text { "Eric" }\end{array}$ & 5 & $\begin{array}{l}\text { One day, while Eric was playing with his friends, a 7-year- } \\
\text { old boy came over and started playing with his private } \\
\text { parts. When Eric came home, his mom noticed that he } \\
\text { wasn't very active like he usually was. When his mom asked } \\
\text { him what had happened, Eric responded, "my dudu [penis] } \\
\text { is paining." Hearing this, his mother became concerned and } \\
\text { brought him to the police station. }\end{array}$ & $\begin{array}{l}\text { The VSU officer on duty interviewed Eric and } \\
\text { his mother together. Since Eric didn't say } \\
\text { much, his mother did much of the explaining. } \\
\text { Eric only said, "my dudu [penis] is paining." } \\
\text { The VSU officer briefly examined the } \\
\text { survivor. Then, he issued a medical report } \\
\text { form and escorted Eric and his mother to } \\
\text { UTH. }\end{array}$ & $\begin{array}{l}\text { Eric was escorted to UTH at II:25 AM. He } \\
\text { was interviewed by the doctor in the presence } \\
\text { of the VSU officer and a counselor. Later, the } \\
\text { VSU officer was asked to leave while the } \\
\text { doctor conducted the physical examination. }\end{array}$ \\
\hline 6 "Fanny" & 8 & $\begin{array}{l}\text { One day, while Fanny was watching TV, her uncle called } \\
\text { her into a bedroom and raped her. "I did not tell anyone } \\
\text { because he told me he would kill me," Fanny said. }\end{array}$ & $\begin{array}{l}\text { The survivor seemed uncomfortable at the } \\
\text { police station but after a while, she managed } \\
\text { to answer the VSU officer's questions. The }\end{array}$ & $\begin{array}{l}\text { At UTH, Fanny had to wait } 2 \text { hours to be seen. } \\
\text { The escorting police officer said, "it seemed as } \\
\text { if the hospital staff did not pay attention to our }\end{array}$ \\
\hline
\end{tabular}




\begin{tabular}{|c|c|c|c|c|}
\hline Case & Age & The Incident & Access to and Experience at VSU & Referral to and Experience at UTH \\
\hline & & $\begin{array}{l}\text { "Neighbors saw that I wasn't walking properly and told my } \\
\text { other uncle." Her 'other uncle' took her to the clinic and } \\
\text { then to the police station. }\end{array}$ & $\begin{array}{l}\text { officer issued a medical report form and } \\
\text { escorted Fanny and her mother to UTH. }\end{array}$ & $\begin{array}{l}\text { case." She was counseled and examined by a } \\
\text { doctor. After the examination, she was happy } \\
\text { because she had been given jiggies [corn snack] } \\
\text { and a drink. Her mother said, "now this is the } \\
\text { way she is at home. She talks a lot." }\end{array}$ \\
\hline $\begin{array}{c}7 \\
\text { "Gondwe" }\end{array}$ & 12 & $\begin{array}{l}\text { While Gondwe was running an errand, she ran into a male } \\
\text { acquaintance. He asked Gondwe if she wanted a phone. } \\
\text { Gondwe eagerly said yes and followed the man to his house } \\
\text { and later, to an unfinished house nearby. He pulled her } \\
\text { inside and raped her. The next morning, "he wanted to } \\
\text { comfort me by throwing his arms around me." When } \\
\text { Gondwe's mother found out, she beat her up and bought } \\
\text { her to the police. }\end{array}$ & $\begin{array}{l}\text { Gondwe and her mother were interviewed } \\
\text { by the VSU officer. Gondwe freely explained } \\
\text { what had happened. The VSU officer issued a } \\
\text { medical report form and escorted Gondwe } \\
\text { and her mother to UTH. }\end{array}$ & $\begin{array}{l}\text { At UTH, Gondwe had to wait a while to be } \\
\text { seen. She was first counselled and then } \\
\text { underwent medical examination. Later, she } \\
\text { was given some medicine. }\end{array}$ \\
\hline $\begin{array}{c}8 \\
\text { "Hamalambo" }\end{array}$ & 12 & $\begin{array}{l}\text { Hamalambo's mother noticed that she seemed depressed } \\
\text { and asked her what was wrong. Hamalambo said, "uncle } \\
\text { slept with me." When Hamalambo's mother tried to ask } \\
\text { for more information, Hamalambo became completely } \\
\text { unresponsive, so she brought her to the police station. }\end{array}$ & $\begin{array}{l}\text { Hamalambo has special needs and at the time, } \\
\text { she was uncomfortable talking to the police. } \\
\text { Her mother answered questions during the } \\
\text { interview. At one point, Hamalambo chimed } \\
\text { in to say, "Mum when uncle comes home } \\
\text { again, do not feel sorry for him. You must } \\
\text { chase him." The VSU officer on duty issued a } \\
\text { medical report form and escorted } \\
\text { Hamalambo and her mother to UTH. }\end{array}$ & $\begin{array}{l}\text { When Hamalambo, her mother, and the } \\
\text { escorting VSU officer went to the One-Stop } \\
\text { Centre at the Paediatric Centre for } \\
\text { Excellence, they found that it was closed so } \\
\text { they went to the Casualties police post and } \\
\text { asked for the relevant forms. Since they } \\
\text { weren't available, Hamalambo's mother was } \\
\text { asked to make five copies of the form even } \\
\text { though only three are needed per case. } \\
\text { Eventually, Hamalambo received medical care } \\
\text { at the One-Stop Centre. }\end{array}$ \\
\hline 9 "Isabelle" & 16 & $\begin{array}{l}\text { Isabelle used to live in a different province when she met a } \\
\text { man who told her he wanted to marry her. One day, he } \\
\text { invited Isabelle to his house and raped her. This happened } \\
\text { multiple times until Isabelle became pregnant. Her family } \\
\text { asked her to return to Lusaka. Ultimately, Isabelle had a } \\
\text { miscarriage and gave birth to a stillborn. She buried the } \\
\text { child near the police station. A group of people noticed }\end{array}$ & $\begin{array}{l}\text { Isabelle cried as she described what had } \\
\text { happened. The VSU officer explained that he } \\
\text { had to detain her since she had violated law. } \\
\text { Before detaining her, the officer took her to } \\
\text { UTH for medical examination. }\end{array}$ & $\begin{array}{l}\text { At UTH, Isabelle was admitted for treatment } \\
\text { and the VSU officer was told to come back the } \\
\text { following day. }\end{array}$ \\
\hline
\end{tabular}




\begin{tabular}{|c|c|c|c|c|}
\hline \multirow[t]{3}{*}{ Case } & \multirow[t]{3}{*}{ Age } & The Incident & \multirow[t]{2}{*}{ Access to and Experience at VSU } & \multirow[t]{2}{*}{ Referral to and Experience at UTH } \\
\hline & & $\begin{array}{l}\text { that Isabelle was no longer pregnant and had no baby, so } \\
\text { they brought her to the police station. }\end{array}$ & & \\
\hline & & \multicolumn{3}{|c|}{$\begin{array}{l}\text { Follow-up: The same day Isabelle was admitted, hospital staff called the VSU officer to tell him that she wanted to escape from the hospital. The VSU officer } \\
\text { asked if he could bring her back to the station and the hospital staff said, "yes, she has been given treatment and we just wanted to keep her in the hospital } \\
\text { for observation." The VSU officer brought Isabelle back to the station and the next day, she was taken to court. }\end{array}$} \\
\hline $\begin{array}{c}10 \\
\text { "Jane" }\end{array}$ & 14 & $\begin{array}{l}\text { One day, while Jane was drawing water from a borehole, a } \\
\text { male acquaintance came and asked her to come over to his } \\
\text { house. There, he raped her and did not use a condom. Jane } \\
\text { enjoyed the act and when her mother asked her where she } \\
\text { was, Jane lied and said she was with a friend. Her mother } \\
\text { found out and started beating her and when her older } \\
\text { brother found out, he beat her too. The next day, the } \\
\text { brother brought her to the police station. }\end{array}$ & $\begin{array}{l}\text { At the police station, Jane seemed ashamed. } \\
\text { "I'm upset and embarassed. I didn't want this } \\
\text { to be reported at the police." The VSU officer } \\
\text { issued a medical report form and escorted } \\
\text { Jane and her brother to UTH. }\end{array}$ & $\begin{array}{l}\text { At UTH, they reported to the One-Stop } \\
\text { Centre at the Paediatric Centre for } \\
\text { Excellence, but were asked to go collect a file } \\
\text { in another department. It took } 4 \text { hours for Jane } \\
\text { to be seen. Later, she was examined and given } \\
\text { ECP. }\end{array}$ \\
\hline $\begin{array}{l}\text { II } \\
\text { "Kisani" }\end{array}$ & 6 & $\begin{array}{l}\text { Kisani was walking back after playing with her cousins at } \\
\text { her aunt's house. On the way back, Kisani's cousins saw } \\
\text { her being picked up by a man standing near an unfinished } \\
\text { house. When the aunt heard this, she left immediately to } \\
\text { go find Kisani. When asked where she was, Kisani said, "A } \\
\text { man called me and said that I should follow him so he could } \\
\text { buy me some jiggies [corn snack]. He took me to some } \\
\text { house and removed my pants. Then he... He told me not } \\
\text { to shout or say anything to anyone because he was going } \\
\text { to buy some jiggies for me but he never did." Her aunt and } \\
\text { her mother immediately brought her to the police station. }\end{array}$ & $\begin{array}{l}\text { At the police station, Kisani was } \\
\text { uncomfortable and did not talk. Her aunt told } \\
\text { the VSU officer what had happened. The } \\
\text { officer issued a medical report form and } \\
\text { escorted Kisani and her mother to UTH. }\end{array}$ & $\begin{array}{l}\text { Kisani and her mother were escorted to UTH } \\
\text { around I0:30 AM. They were asked to register } \\
\text { at one department and then sent to the One- } \\
\text { Stop Centre for further treatment. At the } \\
\text { police post, Kisani's mother was asked to make } \\
\text { photocopies of some forms. "You said the } \\
\text { whole process was supposed to be free but } \\
\text { photocopying these forms is like paying for } \\
\text { them," she told the escorting police officer. } \\
\text { Kisani was examined and she and her mother } \\
\text { received counseling. }\end{array}$ \\
\hline 12 "Lauren" & 15 & $\begin{array}{l}\text { Lauren went over to her cousin's house. When she arrived, } \\
\text { her cousin sent his wife away on an errand. "He closed the } \\
\text { door and started touching me. I tried to shout for help but } \\
\text { no one came," Lauren said. Two days after she was raped, } \\
\text { Lauren found the courage to tell her step-mother and } \\
\text { father. They brought Lauren to the police station. }\end{array}$ & $\begin{array}{l}\text { At the police station, Lauren struggled to tell } \\
\text { her story. She looked distant and stammered } \\
\text { as she explained the incident. The officer } \\
\text { issued a medical report form and escorted } \\
\text { Lauren and her step-mother to UTH. }\end{array}$ & $\begin{array}{l}\text { At UTH, they reported to the One-Stop } \\
\text { Centre at the Paediatric Centre for } \\
\text { Excellence, but were asked to go collect a file } \\
\text { in another department. Lauren received } \\
\text { counseling and treatment. She was given EC } \\
\text { but according to the escorting police officer, }\end{array}$ \\
\hline
\end{tabular}




\begin{tabular}{|c|c|c|c|c|}
\hline Case & Age & The Incident & Access to and Experience at VSU & Referral to and Experience at UTH \\
\hline & & & & $\begin{array}{l}\text { she and her mother had difficulty } \\
\text { understanding why EC needed to be taken. }\end{array}$ \\
\hline \multirow[t]{2}{*}{$\begin{array}{l}13 \\
\text { "Mary" }\end{array}$} & \multirow[t]{2}{*}{$\begin{array}{l}\text { unkn } \\
\text { own } \\
(14- \\
\text { 15) }\end{array}$} & $\begin{array}{l}\text { A good samaritan saw a man and a girl on a road near the } \\
\text { bus station. As she went closer, she saw the man running } \\
\text { away and realized that the girl was unconscious. The good } \\
\text { samaritan immediately gave the girl some sugar water and } \\
\text { brought her to the police station. }\end{array}$ & $\begin{array}{l}\text { Mary was still unconscious when she was } \\
\text { brought to the police station. The good } \\
\text { samaritan suspected that Mary had been } \\
\text { raped because she had seen fluids on Mary's } \\
\text { legs. The VSU officer issued a medical report } \\
\text { form and escorted Mary to UTH. }\end{array}$ & $\begin{array}{l}\text { Mary regained consciousness when she } \\
\text { reached UTH. Since it was late, the One-Stop } \\
\text { Centre at the Paediatric Centre for Excellence } \\
\text { was closed, so she was taken to another } \\
\text { department. She was was admitted since she } \\
\text { was so weak and the VSU officer was advised } \\
\text { to come back the following day. }\end{array}$ \\
\hline & & \multicolumn{3}{|c|}{$\begin{array}{l}\text { Follow-up: The VSU officer went back the next day and spoke to the nurse in charge. She confirmed that Mary had been raped and was still admitted. Mary } \\
\text { was still in shock and was not talking. }\end{array}$} \\
\hline $\begin{array}{l}14 \\
\text { "Namataa" }\end{array}$ & 14 & $\begin{array}{l}\text { Namataa was walking with her friend when two men she } \\
\text { knew grabbed her and pulled her inside an unfinished } \\
\text { house. "I tried to shout for help but no one came. One of } \\
\text { the men covered my mouth while the other man took off } \\
\text { my underpants and slept with me," Namataa said. When } \\
\text { she came home, Namataa told her grandmother who } \\
\text { immediately brought her to the police station. }\end{array}$ & $\begin{array}{l}\text { At the police station, Namataa seemed } \\
\text { reluctant to speak. She would often cross her } \\
\text { arms and not speak. Though she relayed the } \\
\text { basics of the incident, at one point her } \\
\text { grandmother said, "please tell the officer the } \\
\text { truth so that he can help us." The VSU officer } \\
\text { did not probe further. He issued a medical } \\
\text { report form and escorted Namataa and her } \\
\text { grandmother to UTH. }\end{array}$ & $\begin{array}{l}\text { At UTH, they reported to the One-Stop } \\
\text { Centre at the Paediatric Centre for } \\
\text { Excellence, but were asked to go collect a file } \\
\text { in another department. When they returned } \\
\text { to PCOE, Namataa was seen almost } \\
\text { immediately. No details on treatment are } \\
\text { available. }\end{array}$ \\
\hline $\begin{array}{l}15 \\
\text { "Olivia" }\end{array}$ & 15 & $\begin{array}{l}\text { One evening, Olivia went over to her boyfriend's house. } \\
\text { While they were watching TV, Olivia's boyfriend raped her. } \\
\text { It was Olivia's first time and they did not use protection. } \\
\text { "You told me we would chat," she said to her boyfriend. } \\
\text { "Take me home. My mom wants me home." Her boyfriend } \\
\text { took her home and told her not to tell anyone. Olivia told } \\
\text { her mother, who immediately brought her to the police } \\
\text { station. }\end{array}$ & $\begin{array}{l}\text { Olivia looked scared but was able to explain } \\
\text { the whole ordeal. The VSU officer issued ECP } \\
\text { and offered to escort Olivia and her mother } \\
\text { to UTH. Her mother declined and asked if } \\
\text { they could be escorted tomorrow. The } \\
\text { following day, the officer escorted Olivia and } \\
\text { her mother to UTH. }\end{array}$ & $\begin{array}{l}\text { At UTH, they went to the One-Stop Centre at } \\
\text { the Paediatric Centre for Excellence, but a } \\
\text { nurse questioned Olivia's age and her account } \\
\text { of the incident. "We don't want to put people } \\
\text { who are innocent in a problem," she said. They } \\
\text { were referred to another department. After } \\
\text { waiting a while, Olivia was examined and given } \\
\text { PEP. }\end{array}$ \\
\hline 16 "Patricia" & 12 & $\begin{array}{l}\text { One weekend, Patricia was playing with her friends at her } \\
\text { aunt's house. As it got darker, she realized she was lost. } \\
\text { She started asking people for help and soon, she found a }\end{array}$ & $\begin{array}{l}\text { At the station, Patricia cried and had } \\
\text { difficulties explaining what had happened. She } \\
\text { was worried she would not be safe but once }\end{array}$ & $\begin{array}{l}\text { At UTH, they went to the One-Stop Centre at } \\
\text { the Paediatric Centre for Excellence, but were } \\
\text { referred to another department to open a file. }\end{array}$ \\
\hline
\end{tabular}




\begin{tabular}{|c|c|c|c|c|}
\hline Case & Age & The Incident & Access to and Experience at VSU & Referral to and Experience at UTH \\
\hline & & $\begin{array}{l}\text { man who offered to help her. He took her to his house and } \\
\text { asked her to cook dinner. Since it was late, he said she } \\
\text { should sleep at his house and promised to help her in the } \\
\text { morning. Later that night, he raped her. "It was very painful } \\
\text { and I started crying and shouting," Patricia said. "He } \\
\text { threatened to kill me if I told anyone." The next morning, } \\
\text { she woke up and explained everything to his neighbors, } \\
\text { who brought her and the accused man to the police. }\end{array}$ & $\begin{array}{l}\text { the man was detained in a cell, she opened } \\
\text { up. The VSU officer issued a medical report } \\
\text { form and took her to UTH. Since the } \\
\text { neighbors didn't want to accompany, the VSU } \\
\text { officer escorted Patricia in the company of a } \\
\text { female police officer. }\end{array}$ & $\begin{array}{l}\text { As Patricia stepped on the scale, the nurse } \\
\text { attending to her rudely said, "your legs are } \\
\text { dirty." Patricia started to cry. Once her } \\
\text { medical examination was complete, the VSU } \\
\text { officer coordinated with the hospital staff to } \\
\text { refer Patricia to YWCA for temporary } \\
\text { housing. }\end{array}$ \\
\hline I7 "Rachel" & 15 & $\begin{array}{l}\text { Rachel's boyfriend forced her to have sex with him one day } \\
\text { when she was at his house. Three months later, she went } \\
\text { to the clinic and found out that she was pregnant. When } \\
\text { she called her boyfriend to relay the news and tell him that } \\
\text { she would like to continue her education, he said he would } \\
\text { support the child and her education. One day, Rachel told } \\
\text { her aunt what had happened. "She sent me to go buy a } \\
\text { drink and some carfemol [painkillers]." Soon after drinking } \\
\text { the mixture, she started feeling unwell. When she went to } \\
\text { the clinic, she was told that she had lost her child. Upon } \\
\text { hearing this news, she and her mother decided to come to } \\
\text { the police station. }\end{array}$ & $\begin{array}{l}\text { The VSU officer on duty asked Rachel if she } \\
\text { was comfortable with who was in the room. } \\
\text { Rachel requested to be interviewed alone and } \\
\text { the VSU officer respectfully asked the mother } \\
\text { to leave. Rachel then told her story without } \\
\text { hesitation. The VSU officer issued a medical } \\
\text { report form and escorted Rachel and her } \\
\text { mother to UTH. }\end{array}$ & $\begin{array}{l}\text { Rachel received a blood test, a medical exam, } \\
\text { and counseling for } 20 \text { minutes. When they } \\
\text { were back at the police station, Rachel's } \\
\text { mother said, "I am very happy with the help } \\
\text { you have given us. We would not have } \\
\text { managed on our own." Rachel said, "Sir do not } \\
\text { arrest my aunt over what she did." }\end{array}$ \\
\hline \multirow[t]{2}{*}{$\begin{array}{c}18 \\
\text { "Sarah" }\end{array}$} & \multirow[t]{2}{*}{14} & $\begin{array}{l}\text { One afternoon, Sarah went to a friend's house to copy } \\
\text { some notes. Her friend escorted her back and on the way, } \\
\text { they stopped by at a male acquaintance's house. Later, he } \\
\text { escorted Sarah back home. "When I reached home, I found } \\
\text { that all the doors were closed and everyone was asleep," } \\
\text { she said. Sarah's friend offered to let her spend the night at } \\
\text { his place. They had sex without a condom. When she } \\
\text { returned home the next morning, "my father dragged me } \\
\text { straight to the police station." }\end{array}$ & $\begin{array}{l}\text { The VSU officer on duty asked Sarah if she } \\
\text { was comfortable with who was in the room. } \\
\text { Sarah requested to be interviewed alone and } \\
\text { the VSU officer respectfully asked the mother } \\
\text { to leave. After that, she spoke freely. The } \\
\text { VSU officer administered ECP and escorted } \\
\text { Sarah and her mother to UTH. }\end{array}$ & $\begin{array}{l}\text { At UTH, they reported to the One-Stop } \\
\text { Centre at the Paediatric Centre for } \\
\text { Excellence, but were asked to go collect a file } \\
\text { in another department. She received HIV PEP, } \\
\text { a medical examination, and an hour-long } \\
\text { counseling session. She was referred and given } \\
\text { an appointment for behavior change } \\
\text { counseling. }\end{array}$ \\
\hline & & \multicolumn{3}{|c|}{ Follow-up: The following week, the VSU officer escorted Sarah to UTH for her counseling appointment. } \\
\hline
\end{tabular}




\begin{tabular}{|c|c|c|c|c|}
\hline Case & Age & The Incident & Access to and Experience at VSU & Referral to and Experience at UTH \\
\hline $\begin{array}{c}19 \\
\text { "Temwani" }\end{array}$ & 13 & $\begin{array}{l}\text { Temwani and her friend were asked to go sweep at a } \\
\text { nearby house. When they went to the house, they found } \\
\text { two men sitting aside. As they started sweeping, one of the } \\
\text { men pulled Temwani into a room and raped her while his } \\
\text { friend raped Temwani's friend in another room. Temwani's } \\
\text { brother saw her leaving the house and alerted their aunt. } \\
\text { When her aunt inquired about the incident, Temwani told } \\
\text { her what had happened and they both came to the police } \\
\text { station. }\end{array}$ & $\begin{array}{l}\text { Temwani's aunt did most of the explaining } \\
\text { and when the VSU officer asked, Temwani } \\
\text { gave her rendition of the incident. The VSU } \\
\text { officer issued a medical report form and } \\
\text { escorted Temwani and her aunt to UTH. }\end{array}$ & $\begin{array}{l}\text { At UTH, they reported to the One-Stop } \\
\text { Centre at the Paediatric Centre for } \\
\text { Excellence, but were asked to go collect a file } \\
\text { in another department. Later, Temwani was } \\
\text { examined and given some medicine. Details on } \\
\text { the treatment are not available. When they } \\
\text { reached the police station, Temwani's aunt } \\
\text { said, "thank you very much, I could not have } \\
\text { managed on my own." }\end{array}$ \\
\hline $\begin{array}{c}20 \\
\text { "Veronica" }\end{array}$ & 14 & $\begin{array}{l}\text { Vernoica and her friend Yvonne (also a survivor) were } \\
\text { running errands at a market one evening. On the way } \\
\text { home, two men started shouting and running after them. } \\
\text { "While running away, I fell on the ground," Veronica said. } \\
\text { "They caught me and dragged me to an unfinished building." } \\
\text { Veronica and her friend Yvonne were raped. When they } \\
\text { heard voices outside, the assailants ran away. Veronica's } \\
\text { aunt eventually found her and started to beat her up. } \\
\text { "What are you doing here?" she said to Veronica. "Did you } \\
\text { plan to be here with these guys?" Her aunt bought Veronica } \\
\text { and Yvonne to the police station. }\end{array}$ & $\begin{array}{l}\text { Veronica had to be dragged into the police } \\
\text { station by her aunt. She was hesitant to talk } \\
\text { but after the VSU officer assured her that she } \\
\text { was safe, she said, "I was scared you would } \\
\text { beat me...I don't like police officers." As } \\
\text { Veronica told her story, she asked the police } \\
\text { officer to tell her aunt not to beat her. The } \\
\text { aunt said, "I've heard you and I won't do it } \\
\text { again." The VSU officer issued ECP and } \\
\text { escorted Veronica, her aunt, and the other } \\
\text { survivor and her aunt to UTH. }\end{array}$ & $\begin{array}{l}\text { At UTH, they reported to the One-Stop } \\
\text { Centre at the Paediatric Centre for } \\
\text { Excellence, but were asked to go collect a file } \\
\text { in another department. It took } 2.5 \text { hours for } \\
\text { Veronica to be seen. She complained about } \\
\text { being hungry and was given biscuits by hospital } \\
\text { staff. Eventually, she was examined. Details on } \\
\text { the treatment are not available. }\end{array}$ \\
\hline $\begin{array}{c}21 \\
\text { "Yvonne" }\end{array}$ & 14 & $\begin{array}{l}\text { Yvonne was raped in the same situation as Veronica. She } \\
\text { described the same story and added that there was a } \\
\text { group of five men chasing them. She also said the assailants } \\
\text { had threated her by saying he would remove her heart if } \\
\text { she shouted. Her aunt was also with Veronica's aunt when } \\
\text { she came to find her. Yvonne and Veronica were brought } \\
\text { to the police station by their aunts. }\end{array}$ & $\begin{array}{l}\text { Yvonne was willing to come to the police } \\
\text { station unlike her friend, Veronica. She was } \\
\text { hesitant to speak but eventually she relayed } \\
\text { her rendition of the incident. The VSU officer } \\
\text { issued ECP and escorted Yvonne, Veronica, } \\
\text { and their aunts to UTH. }\end{array}$ & $\begin{array}{l}\text { At UTH, they reported to the One-Stop } \\
\text { Centre at the Paediatric Centre for } \\
\text { Excellence, but were asked to go collect a file } \\
\text { in another department. It took } 3 \text { hours for } \\
\text { Yvonne to be seen. She was examined and } \\
\text { given PEP. On the way back to the station, } \\
\text { Yvonne's aunt asked the VSU officer if he } \\
\text { would take them back to UTH for a follow-up } \\
\text { appointment but he said no. }\end{array}$ \\
\hline
\end{tabular}

